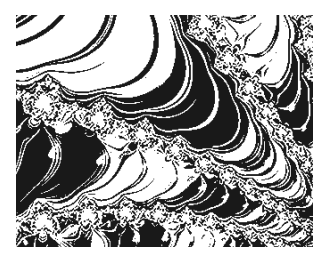

https://doi.org/10.5559/di.29.2.02

\title{
PERCEPTION OF \\ ADULTHOOD AND \\ PSYCHOLOGICAL \\ ADJUSTMENT IN \\ EMERGING ADULTS
}

Ivanka ŽIVČIĆ-BEĆIREVIĆ, Sanja SMOJVER-AŽIĆ,

Tamara MARTINAC DORCIĆ

Faculty of Humanities and Social Sciences, Rijeka

UDK: 159.923.2-053.67

159.922 .8

Izvorni znanstveni rad

Primljeno: 31. 10. 2018.

This work has been fully supported by the University of Rijeka under the project number 13.04.1.3.15.
One of the goals of the study was to check the differences in perception of adult status and fulfilment of achieved subjective criteria of adulthood regarding the transitional markers (professional status and living with parents) and gender. Another goal was to test the contribution of transitional markers, achieved subjective criteria of adulthood and perceived adult status on anxiety, depression and life satisfaction, with control of demographics. A sample of 572 university students, the employed, and the unemployed emerging adults, has been assessed. The measures included Depression and Anxiety Stress Scale, The Satisfaction with Life Scale, Achieved Criteria for Adulthood and Adult Status. The results show that the employed perceived the highest number of achieved adulthood criteria. After controlling for transitional markers, fewer achieved criteria of adulthood predict more symptoms of anxiety and depression. Emerging adults who perceive more achieved criteria of adulthood and who feel as adults have higher life satisfaction. The unemployed young adults, especially men, are at higher risk of having poor psychological adjustment as they struggle with the full realization of an adult role.

Keywords: anxiety, depression, life satisfaction, emerging adults, criteria of adulthood

Ivanka Živčić-Bećirević, Department of Psychology, Faculty of Humanities and Social Sciences, University of Rijeka, Sveučilišna avenija 4, 51000 Rijeka, Croatia. 


\section{Transition to adulthood}

According to Arnett's theory, emerging adulthood is a developmental period that is positioned between the end of adolescence (around age 18) and the entry to stable adulthood, which in more developed countries is prolonged until about age 29 (Arnett, 2014). This period is characterized by self-exploration, contemplation about future opportunities, and continued identity development (Arnett, 2000, 2014). At the end of secondary school, formal social institutions and informal social norms provide less structure, whilst, at the individual level, increased individualization results in more choices and a greater need for personal agency when dealing with a diverse set of potential life changes. The challenges involve both transitional markers (such as leaving the parental home; getting married; becoming parents; having a job) and individual ones (e.g. building their own identity and relations with others).

With more prolonged educational pathways, and rising median ages of marriage and parenthood, emerging adulthood is less well-defined and more unstable than in the past (Arnett, 2000). According to a number of studies (e.g., Arnett, 2016; Sirsch, Dreher, Mayr, \& Willinger, 2009; Žukauskiené, 2016), the majority of young people in their twenties view themselves as being in a transition toward adulthood. Perception of this age period is related to fulfilling different criteria of adulthood that refer to distinct conceptual categories such as Independence (e.g., not deeply attached to parents emotionally), Interdependence (e.g., committed to long-term romantic relationships), and Family Capacities (e.g., capable of caring for children) (Kins \& Beyers, 2010; Zupančič, Komidar, \& Levpušček, 2014). The studies consistently find that young people use more internal and individualistic qualities as criteria for adulthood (Sharon, 2016) and that the most important criteria for adulthood are accepting responsibility for oneself, making independent decisions, and financial independence (Arnett \& Padilla-Walker, 2015; Macek, Bejček, \& Vaníčková, 2007; Sirsch et al., 2009).

Due to different experiences, transition to adulthood is characterized by increased heterogeneity (Schulenberg \& Schoon, 2012). For a large number of young people in their early twenties, college is an important step in the transition from adolescence to adulthood and nowadays one of the most common choices (Zorotovich, 2014). Since most of the research on emerging adulthood has focused mainly on college students, 
DRUŠ. ISTRAŽ. ZAGREB GOD. 29 (2020), BR. 2, STR. 195-215

ŽIVČIĆ-BEĆIREVIĆ, I., SMOJVER-AŽIĆ, S., MARTINAC DORČIĆ, T.: PERCEPTION OF.. differences in perceived adult status between college students and working and unemployed individuals have not been systematically explored (Arnett, 2000; Nelson, Willoughby, Rogers, \& Padilla-Walker, 2015; Seiffge-Krenke, 2016). As it is expected that the college setting more so than the work setting could be associated with identity exploration (Chickering \& Reisser, 1993), emerging adults in college might be less likely than emerging adults at work to view themselves as adults (Arnett, 2000). Those who do not go to college might be constrained to take roles that lead them to feel adult at an earlier age. Finding stable work and identifying one's work as a "career" are important milestones in the successful transition to adulthood (Arnett, 2014). Entrance into work life usually leads to financial independence, which is an important criterion for perceiving oneself as an adult, and influences future goals concerning other adult roles, such as marriage and parenthood (Arnett, 1998). The complexity of the transition to adulthood is increased by the fact that it is no longer a single transition, but a series of micro-transitions, with a yo-yo trend (Biggart \& Walther, 2006). It is also a demographically dense period (Shanahan, 2000) with multiple transitions related to social role, residence, work, and education, all within a relatively short time. However, transition to adulthood differs in different cultures even within European context (Piumatti, Giannotta, Roggero, \& Rabaglietti, 2013; Žukauskiené, 2016). Moreover, gender differences should also be considered. It was found that a higher percentage of men tend to consider themselves to be adults than do women (Nelson \& Luster, 2015), although it is not confirmed in all studies (e.g. Seiffge-Krenke, 2016; Vleioras \& Mantziou, 2018; Zupančič et al., 2014). Related literature has found gender differences in the criteria they deem necessary for adulthood (Sharon, 2016). Conflicting societal messages about the "proper" roles of women at home and at work create a greater challenge to young women to identify themselves as adults (Sharon, 2016; Sirsch et al., 2009).

\section{Adjustment issues in emerging adulthood}

Becoming an adult does not only mean feeling like an adult. It also implies overcoming a series of challenges while maintaining one's own psychological well-being (Tagliabue, Lanz, \& Beyers, 2014). Results on the relationship between the transition to adulthood and well-being confirmed that more achieved criteria for adulthood contribute to a positive change in emerging adults' well-being over time (Arnett, 2000; Kins \& Beyers, 2010; Nelson \& Barry, 2005). Better well-being is related to growing psychosocial maturity after successfully accomplish- 
DRUŠ. ISTRAŽ. ZAGREB GOD. 29 (2020), BR. 2, STR. 195-215

ŽIVČIĆ-BEĆIREVIĆ, I., SMOJVER-AŽIĆ, S., MARTINAC DORČIĆ, T.: PERCEPTION OF... ing developmental tasks concerning autonomy, education, work, and intimate relationships (Galambos, Barker, \& Krahn, 2006; Zupančič et al., 2014).

With the increase in opportunities and still minor immediate responsibilities, emerging adults could have different experiences in viewing the multitude of options. While for some of them the opportunities are exciting and empowering, others become more confused and depressed (Kenny \& Sirin, 2006). The Galambos et al. (2006) longitudinal study showed that "emerging adulthood is not a positive experience for everyone as there is great interindividual variability in intraindividual change" (p. 362). A feeling of freedom to explore different options could result in excitement but hopes and dreams could also result in anxieties and doubts concerning individual competencies and possibilities as well as others' behaviors and expectations (Arnett, 2014; Macek et al., 2007; Schulenberg \& Schoon, 2012).

Along with the increased heterogeneity of pathways during the transition to adulthood, it is expected that there will be increased heterogeneity in mental health and well-being trajectories. Those with good well-being could have the psychological and social resources to successfully negotiate the transitions, and those already having problems could face more difficulties in negotiating these transitions (Schulenberg \& Zarrett, 2006). Although studies confirm continuities in internalizing and externalizing symptoms from adolescence to adult age (Howard, Galambos, \& Krahn, 2010), an emerging adult's subjective well-being could also depend on perceptions of the achieved criteria for adulthood. Those who see themselves as being neither adolescents nor adults might feel depressed and anxious, especially if they believe that they should feel more adult at their current age than they actually do. The instability of emerging adulthood can be especially troubling when changes are involuntary.

\section{Role transition and psychological adjustment in emerging adulthood}

Although studies confirmed that an unemployed status has been associated with increased risk of depression, anxiety and frustration as a consequence of this circumstance (Arnett, Žukauskienè, \& Sugimura, 2014; Paul \& Moser, 2009), more research on the mental health consequences of underemployment among emerging adults, regarding their perception of achieved criteria of adulthood, is needed. It is especially relevant for countries suffering economic crises (high unemployment) like Croatia, where the percentage of unemployed young 
DRUŠ. ISTRAŽ. ZAGREB GOD. 29 (2020), BR. 2, STR. 195-215

ŽIVČIĆ-BEĆIREVIĆ, I., SMOJVER-AŽIĆ, S., MARTINAC DORČIĆ, T.: PERCEPTION OF...

the general population (Matković, 2008). During the last decade, youth unemployment rates have increased in Europe (Caliendo \& Schmidl, 2016), and in the USA (McGee \& Thompson, 2015). According to Eurostat (2018a), the youth unemployment rate was $17.2 \%$ in 28 EU countries, and $27 \%$ in Croatia, as the consequence of a prolonged economic crisis in the country. Additionally, young people in the European countries are often temporarily employed. These kinds of precarious work positions often include uncertainty, unpredictability and insecurity, which may have adverse effects on psychological adjustment (e.g. Ciairano, Rabaglietti, Roggero, \& Callari, 2010; Piumatti et al., 2013).

Besides an increased unemployment rate among the youth, the amount of emerging adults living with parents has increased as well. This trend is more pronounced in Southern European and Mediterranean countries than in Northern Europe or the United States (Iacovou, 2002; Žukauskiené, 2016). Because they cannot afford their desired housing independence, most young people in Croatia, particularly men, live with their parents for much longer. On average, young women moved out of the parental home earlier than young men in all EU Member States, but this gender gap is especially big in Croatia, where the average age for men leaving the parental home in 2016 was 33 years and for women 29.7 (Eurostat, 2018b). Only during college years, most of the students move temporarily from their family home. During the transition to adulthood, independent living appears to be associated with an accelerated attainment of certain criteria for adulthood, whereas continued co-residence with parents stunts this process (Kins \& Beyers, 2010).

The specific socio-cultural context of becoming an adult in Croatia (especially a high unemployment rate, somewhat difficult school to work transition, prolonged living with parents) might interfere with taking a full adult role and reflect on the psychological adjustment of emerging adults. As traditional gender roles are still present in our culture, we have assumed that effects of transitional markers might be different for males and females.

\section{STUDY GOALS}

The main aim of this study is to investigate the relationship between subjective and objective transitional criteria of adulthood, perceived adult status and psychological functioning in emerging adults in Croatia. The specific goals are:

1. To check the differences in young people's perception of adult status and overall achieved subjective criteria of adult- 
DRUŠ. ISTRAŽ. ZAGREB GOD. 29 (2020), BR. 2, STR. 195-215

ŽIVČIĆ-BEĆIREVIĆ, I., SMOJVER-AŽIĆ, S. MARTINAC DORČIĆ, T.: PERCEPTION OF...

\section{METHOD}

\section{Participants}

hood, regarding the transitional markers (professional status and living with parents) and gender.

2 . To test the contribution of transitional markers (professional status, living with or away from parents, having a romantic partner), achieved overall subjective criteria of adulthood and perceived adult status on different aspects of psychological adjustment, with control of demographics (age and gender). We have measured psychological adjustment through life satisfaction, as the most common measure of well-being, and anxiety and depression, as usual measures of psychological distress.

Based on the presented theory of emerging adulthood (Arnett, 2014) and empirical findings from other studies, it is hypothesized that among the three groups in regards to professional status, the employed young adults will perceive they achieved the most criteria of adulthood. More students than the employed or the unemployed emerging adults will perceive themselves in transition toward adulthood but not fully adults. Unemployed emerging adults and students will report more symptoms of anxiety and depression, as well as lower life satisfaction in comparison with the employed ones. We do not expect a difference in the subjective criteria of adulthood and perceived adult status regarding living with parents and gender. Based on the results of previous studies (Howard et al., 2010; Nelson \& Barry, 2005), it is hypothesized that the subjective criteria of adulthood and perceived adult status will independently contribute to better psychological adjustment, after controlling for transitional markers, age and gender.

The non-probabilistic convenience sample included a total of 572 emerging adults (54\% females) between 19 and 28 years of age (Mage $=23.08)$. There were three groups of participants based on their professional status: students $(N=297$; Mage $=21.74)$, the employed $(N=171$; Mage $=24.83)$ and the unemployed $(N=104 ;$ Mage $=24.18)$. Among the employed $56.6 \%$ have finished college and among the unemployed $54.8 \%$. The average duration of the unemployment status is 11.5 months and the average employment status is 34 months.

Among all participants, $54 \%$ are in a relationship (66\% of the unemployed, $48 \%$ of the students and $60 \%$ of the employed) and $51.6 \%$ live with their parents (71.2\% of the unemployed, $39.7 \%$ of the students and $60.2 \%$ of the employed). 
The Conception of the Transition to Adulthood (CTA; Arnett, 2003) is a self-report list of several criteria for adulthood. Participants were asked whether they had achieved each of the criteria themselves. The participants responded to the items with either $0=$ no; $1=$ in some ways yes, in some ways no; or $2=$ yes.

Similarly to Zupančič, Friedlmeier et al. (2014), we used a reduced number (22) of items, including criteria from Independence (e.g. accept responsibility for the consequences of your actions), Interdependence (e.g. learning to always have good control over your emotions), Family Capacities (e.g. capable of running a household), and Norm Compliance (e.g. avoid drunk driving). Biological, Legal/Chronological, and Role Transitions categories (related to employment, marriage, finished school, having a child, independent living) were omitted, because our aim was to focus on respondents' subjective criteria of adulthood. Some of the role transition categories were considered separately as specific transitional markers (professional and relationship status, living arrangements).

The overall indicator of the achieved criteria for adulthood was a sum of all responses (possible range was 0 to 44).

Adult status (Arnett, 1998) was determined by one question "Do you feel that you have reached adulthood". Participants responded with either $0=$ no, $1=$ in some ways yes, in some ways no, or $2=$ yes.

The Depression Anxiety Stress Scales 21 (DASS-21; Lovibond \& Lovibond, 1995) was developed to measure emotional distress in three subcategories (depression, anxiety and stress). It is a self-report questionnaire with 21 items (seven items for each category) based on a four-point rating scale. Participants are asked to rate how many of each of the items applied to them over the past week, from 0 (did not apply to me at all) to 3 (applied to me very much, or most of the time). A higher score indicates more severe emotional distress. We have used only two sub-scales, Depression (e.g. I felt that life was meaningless) and Anxiety (e.g. I found myself getting agitated) as indicators of participants' mental health.

The Satisfaction with Life Scale (Diener, Emmons, Larsen, \& Griffin, 1985) is a 5-item scale designed to measure global cognitive judgements of one's life satisfaction (e.g. In most ways my life is close to my ideal). The participants indicate how satisfying they judge each of the five global aspects of their life to be, using a 5-point scale that ranges from 1 (strongly disagree) to 5 (strongly agree). 
DRUŠ. ISTRAŽ. ZAGREB GOD. 29 (2020), BR. 2, STR. 195-215

ŽIVČIĆ-BEĆİEVIĆ, I., SMOJVER-AŽIĆ, S. MARTINAC DORČIĆ, T.: PERCEPTION OF...
All the measures have an acceptable internal consistency (Table 1).

The demographic questionnaire included data on age, gender, educational level and transitional markers: professional status (student, employed, unemployed), relationship status (with or without partner), living arrangements (living with or without parents), and education level.

After informed consent, the students fulfilled the on-line version of the questionnaire. They were asked to pass along the link with the questionnaire to their employed and unemployed acquaintances (snowball method). Additionally, the link with the questionnaire was active on the relevant web sites. All the information that is collected was anonymous and kept strictly confidential. The data were collected during the years 2016 and 2017.

\section{RESULTS}

\section{Descriptives}

(1) TABLE 1

Descriptive and bivariate correlations
The descriptive characteristics of all variables used in the study as well as their intercorrelations are reported in Table 1 . The average reported level of anxiety and depressive symptoms in our sample is in a normal range, according to other studies using nonclinical samples (Sinclair et al., 2012), while participants reported only slight satisfaction with their life.

\begin{tabular}{|c|c|c|c|c|c|c|c|c|}
\hline & Age 1 & $\begin{array}{l}\text { Living } \\
\text { with } \\
\text { parents }\end{array}$ & $\begin{array}{l}\text { Rela- } \\
\text { tionship } \\
\text { status }\end{array}$ & $\begin{array}{l}\text { Adult } \\
\text { status }\end{array}$ & $\begin{array}{l}\text { Adult- } \\
\text { hood } \\
\text { criteria }\end{array}$ & Anxiety & Depression & $\begin{array}{r}\text { Life } \\
\text { satisfaction }\end{array}$ \\
\hline Living with parents & $0.14^{*}$ & & & & & & & \\
\hline Relationship status & $0.14^{*}$ & -0.05 & & & & & & \\
\hline Adult status & $0.31^{* *}$ & 0.05 & $0.24^{* *}$ & & & & & \\
\hline Adulthood criteria & $0.40^{* *}$ & $-0.21^{* *}$ & $0.38^{* *}$ & $0.49^{* *}$ & & & & \\
\hline Anxiety & -0.05 & 0.02 & 0.02 & $-0.10^{*}$ & $-0.21^{* *}$ & & & \\
\hline Depression & -0.03 & 0.06 & $-0.10^{*}$ & $-0.09^{*}$ & $-0.29^{* *}$ & $0.63^{* *}$ & & \\
\hline Life satisfaction & 0.04 & $-0.17^{* *}$ & $0.15^{* *}$ & $0.30^{* *}$ & $0.40^{* *}$ & $-0.34^{* *}$ & $-0.46^{* *}$ & \\
\hline M & 23.08 & - & - & - & 27.83 & 4.55 & 6.05 & 16.73 \\
\hline$S D$ & 2.55 & - & - & - & 6.45 & 4.22 & 5.08 & 4.22 \\
\hline$\alpha$ & - & - & - & - & 0.77 & 0.82 & 0.88 & 0.83 \\
\hline
\end{tabular}

${ }^{*} p<0.05 ;{ }^{* *} p<0.001$; Note. The coding of the nominal predictors was as follows: Relationship status $(0-$ without romantic partner, 1 - with romantic partner), Living with parents $(0-$ live away from parents, 1 - live with parents). 


\section{Perception of reaching adulthood}

The frequencies of the respondents' answers to the question "Do you feel that you have reached adulthood" regarding pro-

(1) TABLE 2

Frequencies and percentages (in parentheses) of respondents' answers to the question "Do you feel that you have reached adulthood" fessional status, living arrangements and gender is presented in Table 2.

Most of the students feel "in-between", while more of the employed and unemployed perceive themselves as adults $\left(\chi^{2}=\right.$ $50.30, p<0.001)$. The perception of reaching adulthood is similar regardless of living arrangements and gender.

\begin{tabular}{|c|c|c|c|c|c|c|c|c|}
\hline \multirow[b]{2}{*}{ Answer/group } & \multirow[b]{2}{*}{ All } & \multicolumn{3}{|c|}{ Professional status } & \multicolumn{2}{|c|}{$\begin{array}{r}\text { Live } \\
\text { with parents } \\
\end{array}$} & \multicolumn{2}{|r|}{ Gender } \\
\hline & & Students & $\begin{array}{r}\text { Em- } \\
\text { ployed }\end{array}$ & $\begin{array}{l}\text { Unem- } \\
\text { ployed }\end{array}$ & Yes & No & M & $\mathrm{F}$ \\
\hline Yes & $257(44.4)$ & $91(31)$ & $102(60)$ & $61(59)$ & $138(46)$ & $119(43)$ & $128(48)$ & $129(41)$ \\
\hline $\begin{array}{l}\text { In some ways yes, } \\
\text { in some ways no }\end{array}$ & $278(48)$ & 173 (58) & $64(37)$ & $37(35)$ & $141(47)$ & 137 (49) & $118(44)$ & $160(51)$ \\
\hline No & $44(7.6)$ & $33(11)$ & $5(3)$ & $6(6)$ & $20(7)$ & $24(8)$ & $21(8)$ & $23(8)$ \\
\hline$\chi^{2}(d f)$ & & \multicolumn{3}{|c|}{$50.30^{* *}(4)$} & \multicolumn{2}{|c|}{$1.20(2)$} & \multicolumn{2}{|c|}{$2.96(2)$} \\
\hline
\end{tabular}

${ }^{* *} p<0.001$

\section{Differences in adulthood criteria regarding} gender professional status and living arrangements

(1) TABLE 3

Three-way ANCOVA:

Descriptives in

adulthood criteria

regarding gender, professional status and living with parents
Because the three groups of participants differ in age, in order to look at the effect of professional status, gender and living arrangements on adulthood criteria, a 3-way ANCOVA was done, with age as a covariate and Bonferroni correction (Table 3 and Table 4).

\begin{tabular}{|c|c|c|c|c|c|c|c|c|c|}
\hline \multirow{2}{*}{ Variable } & & \multicolumn{2}{|c|}{ Students } & \multicolumn{2}{|c|}{ Employed } & \multicolumn{2}{|c|}{ Unemployed } & \multicolumn{2}{|r|}{ Total } \\
\hline & & $M$ & $S D$ & M & $S D$ & $M$ & $S D$ & $M$ & $S D$ \\
\hline \multirow[t]{3}{*}{ Living without parents } & $\mathrm{M}$ & 24.68 & 5.57 & 32.45 & 6.03 & 36.33 & 4.04 & 27.65 & 6.90 \\
\hline & $\mathrm{F}$ & 27.65 & 5.84 & 35.32 & 4.84 & 34.18 & 5.23 & 30.22 & 6.53 \\
\hline & $\mathrm{T}$ & 26.57 & 5.90 & 33.91 & 5.61 & 34.40 & 5.11 & 29.28 & 6.77 \\
\hline \multirow[t]{3}{*}{ Living with parents } & M & 24.13 & 5.10 & 29.63 & 4.64 & 23.15 & 6.24 & 26.23 & 6.07 \\
\hline & $\mathrm{F}$ & 25.61 & 5.43 & 29.21 & 5.84 & 27.32 & 5.15 & 26.92 & 5.66 \\
\hline & $\mathrm{T}$ & 25.12 & 5.35 & 29.48 & 5.09 & 24.73 & 6.16 & 26.56 & 5.88 \\
\hline \multirow[t]{3}{*}{ Total } & $\mathrm{M}$ & 24.47 & 5.38 & 30.58 & 5.29 & 23.96 & 6.88 & 26.79 & 6.44 \\
\hline & $\mathrm{F}$ & 26.82 & 5.75 & 32.09 & 6.17 & 30.69 & 6.20 & 28.73 & 6.36 \\
\hline & $\mathrm{T}$ & 25.99 & 5.72 & 31.22 & 5.71 & 27.52 & 7.32 & 27.87 & 6.46 \\
\hline
\end{tabular}

The main effects of professional status and living arrangements were significant. Employed young adults achieved the most adulthood criteria in comparison to the students and the unemployed. Additionally, emerging adults who live with- 
out their parents achieved more adulthood criteria than those who live with their parents.

\begin{tabular}{lccc}
\hline Effects & $F$ & $d f$ & $\eta^{2}$ \\
\hline Gender & 3.06 & 1,545 & 0.01 \\
Professional status & $18.11^{* *}$ & 2,545 & 0.06 \\
Living with parents & $57.62^{* *}$ & 1,545 & 0.10 \\
Gender x professional status & 0.74 & 2,545 & 0.00 \\
Gender x living with parents & 0.10 & 1,545 & 0.00 \\
Professional status x living with parents & $8.90^{* *}$ & 2,545 & 0.03 \\
Gender x professional status x living with parents & 2.35 & 2,545 & 0.01 \\
\hline
\end{tabular}

${ }^{* *} p<0.001$

(1) TABLE 4

Results of three-way ANCOVA: Main and interaction effects of gender, professional status and living with parents on adulthood criteria (age as a covariate)

- FIGURE 1

Interaction effect between professional status and living arrangements on achieved adulthood criteria
The only significant interaction effect was between professional status and living arrangements (Figure 1). Post-hoc analysis (Scheffe test) showed that there is no significant difference in the achieved criteria of adulthood among students $(p=$ $0.468)$, while employed $(p<0.01)$ and unemployed $(p<0.001)$ young adults who live independently achieved more criteria of adulthood comparing to the ones who live with their parents. Additionally, employed young adults who live with their parents achieved more adulthood criteria than unemployed ones also living with parents $(p<0.0001)$.

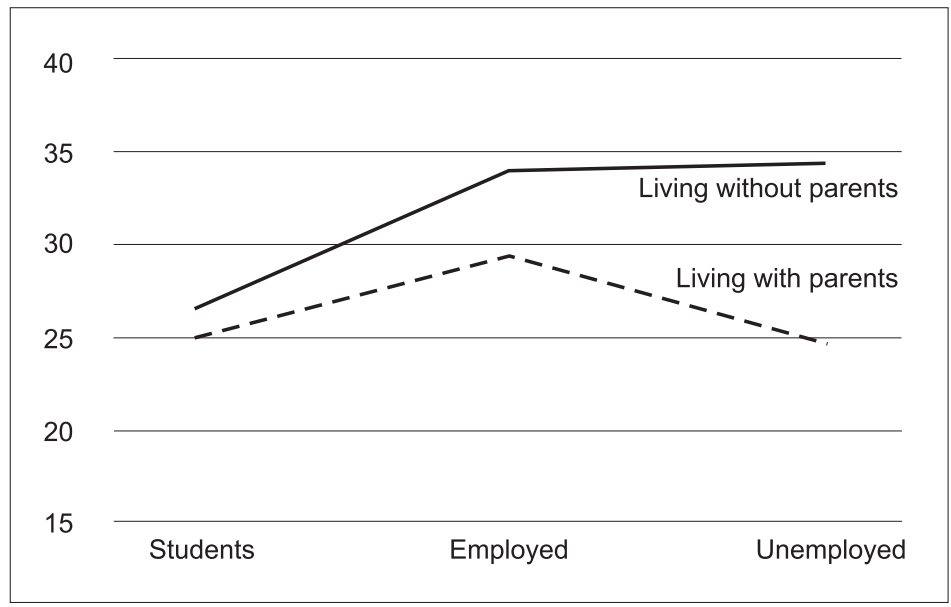

\section{Contribution of achieved criteria of adulthood to psychological adjustment}

In order to examine the contribution of the achieved criteria of adulthood after controlling for age, gender, relationship, living and professional status to anxiety, depression and life satisfaction in emerging adults, three hierarchical regression analyses were performed (Table 5). 
For this analysis, professional status was coded in two dummy variables: the unemployed (vs. students and employed) and the employed (vs. students and unemployed).

\begin{tabular}{|c|c|c|c|c|c|c|c|c|c|c|}
\hline \multirow{2}{*}{\multicolumn{2}{|c|}{ Predictors }} & \multicolumn{3}{|c|}{ Anxiety } & \multicolumn{3}{|c|}{ Depression } & \multicolumn{3}{|c|}{ Life satisfaction } \\
\hline & & $\beta$ & $\Delta R^{2}$ & $R^{2}$ & $\beta$ & $\Delta R^{2}$ & $R^{2}$ & $\beta$ & $\Delta R^{2}$ & $R^{2}$ \\
\hline \multirow[t]{6}{*}{ Step 1} & Age & 0.09 & & $0.05^{* *}$ & 0.06 & & $0.11^{* *}$ & $-0.13^{*}$ & & $0.06^{* *}$ \\
\hline & Gender & $0.12^{*}$ & & & $0.11^{*}$ & & & 0.03 & & \\
\hline & Relationship status & 0.09 & & & -0.04 & & & 0.00 & & \\
\hline & Living with parents & 0.01 & & & -0.05 & & & -0.08 & & \\
\hline & Employed & $-0.15^{*}$ & & & -0.04 & & & 0.02 & & \\
\hline & Unemployed & -0.00 & & & $0.27^{* *}$ & & & -0.08 & & \\
\hline \multirow[t]{2}{*}{ Step 2} & Adulthood criteria & $-0.25^{* *}$ & & & $-0.33^{* *}$ & & & $0.33^{* *}$ & & \\
\hline & Adult status & 0.00 & $0.04^{* *}$ & $0.09^{* *}$ & 0.04 & $0.06^{* *}$ & $0.17^{* *}$ & $0.19^{* *}$ & $0.14^{* *}$ & $0.19^{* *}$ \\
\hline
\end{tabular}

${ }^{*} p<0,01,{ }^{* *} p<0,001$

(1) TABLE 5

Hierarchical regression predicting anxiety, depression, and life satisfaction
Note. Higher scores are indicative of more extreme responding in the direction of the construct assessed. The coding of the nominal predictors was as follows: Gender ( 0 - male, 1 - female), Relationship status ( 0 - without romantic partner, 1 - with romantic partner), Living with parents ( 0 - live away from parents, 1 - live with parents), Employed $(0$ - others, 1 - employed), Unemployed $(0$ - others, 1 - unemployed). $\beta$ from the last step are shown; $\Delta R^{2}$ - contribution of a particular group of predictors to explained variances; $\Delta R^{2}$ - overall contribution to explained variances.

The analyzed variables explained only a small proportion of variance of all three criteria. Demographics better explained the depression, while perceived criteria of adulthood and adult status explained the higher variances in life satisfaction than in psychological symptoms.

Age is a negative predictor of life satisfaction in the second, but not in the first step. This could be a suppressor effect as age is not correlated with life satisfaction, but with criteria of adulthood $(r=0.40 ; p<0.001)$.

Having a partner is a significant negative predictor of depression and a positive predictor of life satisfaction only in the first step. When perceived criteria of adulthood were included, this changed. Similarly, living with parents is a significant negative predictor of life satisfaction only in the first step of the analysis.

Being employed is a significant negative predictor of anxiety and being unemployed is a significant positive predictor of depression. Results also showed that the achieved criteria of adulthood additionally explained a significant proportion of variance of anxiety, depression and life satisfaction. Emerging adults with fewer achieved criteria of adulthood have more symptoms of anxiety and depression. Those who perceive more achieved criteria of adulthood and who feel as adults are more satisfied with their life. 
In this study, the perception of adulthood was investigated by two constructs, the feeling of reaching adulthood and the perception of achieving the criteria of adulthood. These two constructs are moderately correlated in our sample, and both are similarly related to demographics and transitional markers, but have a different contribution to psychological symptoms and well-being.

\section{Differences in adulthood criteria regarding gender, professional status and living with parents}

One of the goals of this study was to check the differences in young people's perception of adult status and overall achieved subjective criteria of adulthood, regarding the transitional markers (professional status and living with parents) and gender. As hypothesized, employed young adults report achieving most of the adulthood criteria in comparison with the other two groups. Entrance into work life or employment usually lead to financial independence, which is one of the most important criteria for perceiving oneself as an adult (Arnett, 2000; Seiffge-Krenke, 2016; Sirsch et al., 2009).

As expected, in response to the single question about reaching adulthood, most of the students (58\%) responded "in some ways yes, in some ways no", which is in line with results in the US, Austrian and Slovenian samples (Nelson \& Barry, 2005; Zupančič et al., 2014), where most of the students view themselves as in transition toward adulthood. The fact that students in our sample are younger than in the other two groups and that the correlation between the age and adult status perception is significant, might partly explain the differences in their perception of adult status. Besides that, one of the main characteristics defining emerging adulthood is that which defines it as an age of possibilities and exploration, which is more common for students. During college years students have more opportunity, they are more encouraged to explore different options and are not forced to take on the adult role.

It is interesting that, despite being younger, fewer students in our sample live with their parents as opposed to the other two groups of young adults (the employed and the unemployed). Students are usually required to move away from home to attend college, but most of them are still somewhat dependent on their family of origin, especially for things such as financial support. This may reflect on them feeling like an adult (Padilla-Walker, Nelson, \& Carroll, 2012). On the other hand, most of the employed and unemployed young adults in our study described themselves as adults, even if many of them still live with their parents. Young adults who live without their parents achieved more criteria of adulthood, but this transitional marker is not relevant for their subjective 
DRUŠ. ISTRAŽ. ZAGREB GOD. 29 (2020), BR. 2, STR. 195-215

ŽIVČIĆ-BEĆIREVIĆ, I., SMOJVER-AŽIĆ, S., MARTINAC DORCIC, T.: PERCEPTION OF.. feeling of reaching adulthood. As many as $46 \%$ of emerging adults (ages 18-34) in the European Union live with their parents (Choroszewicz \& Wolff, 2010). A prolonged co-residence with parents is more common in Mediterranean countries (e.g. Seiffge-Krenke, 2013), while in Northern Europe, emerging adults experiment with different living conditions between moving out of the parental home and starting their own family. Our results suggest that positive effects of living without parents on the achieved criteria of adulthood is the most pronounced among the unemployed.

Arnett and Padilla-Walker (2015) found that emerging adults who are not independent of their parents in their living arrangements measure their own progress to adulthood by criteria other than independence. Sharon (2016) has also found that today's young adults put more weight on more internal and psychological qualities, such as accepting responsibility for their actions and deciding on one's beliefs and values, while giving less priority to more traditional and more objective transition markers in which they may fall short. It seems they put more stress on attaining domains over which they have more control. Once young adults achieve traditional role markers, they are more likely to incorporate them into their definitions of adulthood (Lowe, Dillon, Rhodes, \& Zwiebach, 2013). All of these might suggest a genuine change in young people's sense of what adulthood means, as they try to adjust to social and economic changes, e.g. increasing requirement for post-secondary education, increased unemployment and financial uncertainty. Our study confirms that the difference in biographical transitions, such as entrance into work life, could possibly explain why the time for psychological maturity might not be the same for every individual (Buhl \& Lanz, 2007). According to Arnett (2001), adulthood is multidimensional, with emerging adults feeling that they have achieved adulthood by some criteria but not by others. Besides, views of emerging adulthood should be understood and analyzed while taking into account characteristics and perceptions of the social context in which they develop (Crocetti et al., 2015; Piumatti et al., 2013).

We did not find any gender differences in adult status and achieved subjective criteria of adulthood, which is in line with the results of some other research (e.g. Vleioras \& Mantziou, 2018; Zupančić et al., 2014b).

\section{Contribution of achieved criteria of adulthood and adult status to psychological adjustment}

The other goal of this study was to explore the contribution of transitional markers, achieved overall subjective criteria of adulthood and adult status on the psychological adjustment of emerging adults. Our results confirm the hypothesis that 
DRUŠ. ISTRAŽ. ZAGREB GOD. 29 (2020), BR. 2, STR. 195-215

ŽIVČIĆ-BEĆIREVIĆ, I., SMOJVER-AŽIĆ, S., MARTINAC DORČIĆ, T.: PERCEPTION OF... achieved subjective criteria of adulthood and perceived adult status will contribute to psychological adjustment, after controlling for demographics and transitional markers, although the included variables explain a relatively small proportion of the variance. The achieved criteria of adulthood have a small, but significant, additional effect on all measures of psychological functioning in emerging adults. Results showed that fewer achieved criteria of adulthood predict more symptoms of anxiety and depression, while more achieved criteria of adulthood and subjective perception of being an adult predict higher life satisfaction, which is especially pronounced among employed young adults. Schwartz, Côté, and Arnett (2005) comment that the perception that important needs have been fulfilled leads to satisfaction, while anxiety can be associated with the inability to meet needs in valued areas of life. Kins and Byers (2010) also found that the achievement of criteria for adulthood is related to better subjective well-being, particularly growth in the criteria reflecting independence and interdependence. Schulenberg and Schoon (2012) suggest that those who successfully negotiate the multiple transitions that comprise the global transition to adulthood by the age of 26 , report better health and well-being than their age-mates.

Our results suggest that, among transitional markers, employment status is the most relevant for psychological adjustment. The employed have less anxiety symptoms than the students and the unemployed, while the unemployed have more depressive symptoms in comparison with the other two groups. Developmental factors, such as uncertainty related to the transition to adulthood, may contribute to anxiety symptoms in students and the unemployed.

Depression among unemployed emerging adults may be associated with stress because of delays in achieving development goals related to the transition to adulthood (McGee \& Thompson, 2015). Today, obtaining a degree does not result in getting a stable job and the number of unemployed individuals with university degrees is rising. Many of the young unemployed adults in our sample have finished college $(40 \%)$ and most of them still live with their parents (71\%). It is possible that some of them have started a partially independent life while being at college and, after graduating, they had to move back in with their parents because they could not find a job. Such a situation may be perceived as a failure to accomplish developmental tasks that may result in life dissatisfaction (Schwartz et al., 2005). Moving back in with their parents (a boomerang effect, Arundel \& Lennartz, 2017; Biggart \& Walther, 2006) may be more stressful now than it was at a younger age. According to our results, living with parents is a significant negative predictor of life satisfaction only in the first step of the analysis, but when achieved subjective criteria of adulthood 
DRUŠ. ISTRAŽ. ZAGREB GOD. 29 (2020), BR. 2, STR. 195-215

ŽIVČIĆ-BEĆIREVIĆ, I., SMOJVER-AŽlĆ, S. MARTINAC DORCIC, T.: PERCEPTION OF.. (e.g. accepting responsibility for oneself, making independent decisions, and financial independence) are included, it is not significant any more.

Results of our study are in accordance with consistent data documenting the detrimental impact of unemployment on the mental health of emerging adults including increased risk of developing mental illness (Kuwabara, Van Voorhees, Gollan, \& Alexander, 2007), and increased symptoms of depression and anxiety (Paul \& Moser, 2009). Howard et al. (2010) have found that experiencing longer periods of unemployment was related to lower life and career satisfaction.

In line with the results of Paul and Moser (2009) where men were more distressed by unemployment than women, our results show that unemployment contributes to depressive symptoms more in males than in females. The fact that they are not working and do not have student status is most deleterious for men. This is in accordance with the finding that work is linked most firmly to notions of adulthood for men in 25 European countries (Spéder, Murinkó, \& Settersten 2014). Specifically, in Eastern and Southern Europe, family transitions (living together with a partner and becoming a parent) are the most important markers of adult status for women, while having a full-time job is most important for men. Sharon (2016) suggests that the pathway to adult status may be less well defined for females than for males, while traditional gender roles and criteria of adulthood more clearly expect young men to become financially independent.

In explaining the results regarding mental health of emerging adults with different employment statuses, some general remarks have to be made. According to Tanner (2014), emerging adulthood is associated with increasing mental health in general, but constructive forces of this age period have a stronger effect on those who had few, if any, mental health problems prior to this age period. Early psychopathology could interfere with adjustment and could increase the risk for further psychopathology. As we do not have the data about the psychological status of our participants before entering the age of emerging adulthood, it is possible that some of them have previous psychological problems that interfered with their further development, as well as with their formation of a professional career. There might be a presence of a vicious circle that perpetuates such problems and makes it harder for a young adult to move on.

\section{Limitations and strengths}

This study is not without limitations. We have used only self-report measures with the convenience samples. In addition, the correlational nature of the analysis precludes causal inferences. As this study was cross-sectional, future studies should 
DRUŠ. ISTRAŽ. ZAGREB GOD. 29 (2020), BR. 2, STR. 195-215

ŽIVČIĆ-BEĆIREVIĆ, I., SMOJVER-AŽIĆ, S., MARTINAC DORČIĆ, T.: PERCEPTION OF... follow the representative sample of young adults longitudinally to explore changes in their psychological adjustment during their emerging adulthood years, but also as they change their professional status. We should also keep in mind that the average reported level of anxiety and depressive symptoms in our sample is in a normal range. Still, $20 \%$ of participants have at least a mild or even severe level of anxiety and moderate level of depression. Because our results might be culturally specific, it would be useful to examine these issues in samples of emerging adults in other cultures with similar socio-economic characteristics. Besides, future studies should consider the precarious job condition that may affect psychological adjustment similarly to unemployment. The young adults' importance of criteria proposed for reaching adulthood, as well as the contribution of specific sub-dimensions of achieved adulthood criteria to adjustment, should also be explored.

One of the main strengths of the study is that it explores psychological adjustment in a heterogeneous sample of emerging adults, considering their current professional status in three groups with the control of age, while most studies on emerging adults are focused mainly on college students. Including the group of unemployed young adults was especially valuable as they are commonly difficult to reach, which is reflected in a smaller sample size in this study.

\section{CONCLUSIONS AND PRACTICAL IMPLICATIONS}

This study confirmed that the well-being of emerging adults may be tied to conceptions of adulthood. The importance of professional status in the achieved criteria of adulthood has been confirmed, and is in line with the idea that finding a job is an important milestone in the successful transition into adulthood (Mortimer, Vuolo, Staff, Wakefield, \& Xie, 2008). Namely, among the analyzed transitional markers, professional status was found to be the only important factor, after controlling for age, while living with or without parents and relationship status do not have a significant effect on anxiety, depression and life satisfaction. Unemployed men seem to be at the highest risk for developing psychological problems. Even if most students see themselves as feeling in-between adolescence and adulthood and achieve the least criteria of adulthood as they struggle to negotiate this stressful period of life, it seems that student status may have a protective function. Students have clear roles, expectations, structures, a lot of benefits and support services they can rely on in times of too much stress. On the other hand, unemployed young adults lose all these benefits and enter a period of life full of uncertainty, unpredictability, confusion and instability. 
DRUŠ. ISTRAŽ. ZAGREB GOD. 29 (2020), BR. 2, STR. 195-215

ŽIVČIĆ-BEĆIREVIĆ, I., SMOJVER-AŽIĆ, S., MARTINAC DORČIĆ, T.: PERCEPTION OF..
The results of this study suggest that society should pay more attention to unemployed young adults. Most of them perceive themselves as adults (or they just feel that they should be at that life stage even if they report about achieving fewer criteria of adulthood than the employed), but at the same time they struggle with the full realization of an adult role, which is reflected on their psychological adjustment. It is important to approach unemployed young people as they are often hard to reach, and their status may lead to passivity and helplessness, which results in not asking for help when they need it. Special focus should be on unemployed men, who are more prone to depression and usually less willing to search for help.

Arnett, J. J. (1998). Learning to stand alone: The contemporary American transition to adulthood in cultural and historical context. Human Development, 41(5-6), 295-315. https://doi.org/10.1159/000022591

Arnett, J. J. (2000). Emerging adulthood. A theory of development from the late teens through the twenties. American Psychologist, 55(5), 469-480. https://doi.org/10.1037/0003-066X.55.5.469

Arnett, J. J. (2001). Conceptions of the transition to adulthood: Perspectives from adolescence through midlife. Journal of Adult Development, 8, 133-143. https://doi.org/10.1023/A:1026450103225

Arnett, J. J. (2003). Conceptions of the transition to adulthood among emerging adults in American ethnic groups. New Directions for Child and Adolescent Development, 2003(100), 63-76. https://doi.org/10.1002/cd.75 Arnett, J. J. (2014). Emerging adulthood: The winding road from the late teens through the twenties. New York: Oxford University Press. https:// doi.org/10.1093/acprof:oso/9780199929382.001.0001

Arnett, J. J. (2016). Emerging adults in Europe: Common themes, diverse paths, and future directions. In R. Žukauskiené (Ed.), Emerging adulthood in a European context (pp. 206-215). New York: Psychology Press.

Arnett, J. J., \& Padilla-Walker, L. M. (2015). Brief report: Danish emerging adults' conceptions of adulthood. Journal of Adolescence, 38, 39-44. https://doi.org/10.1016/j.adolescence.2014.10.011

Arnett, J. J., Žukauskienė, R., \& Sugimura, K. (2014). The new life stage of emerging adulthood at ages 18-29 years: Implications for mental health. The Lancet Psychiatry, 1(7), 569-576. https://doi.org/10.1016/ S2215-0366(14)00080-7

Arundel, R. \& Lennartz, C. (2017). Returning to the parental home: Boomerang moves of younger adults and the welfare regime context. Journal of European Social Policy 27(3), 276-294. https://doi.org/10. $1177 / 0958928716684315$

Biggart, A., \& Walther, A. (2006). Coping with yo-yo-transitions: Young adults' struggle for support, between family and state in comparative perspective. In C. Leccardi \& E. Ruspini (Eds.), A new youth? Young people, generations and family life (pp. 41-62). Aldershot: Ashgate. 
DRUŠ. ISTRAŽ. ZAGREB STR. 195-215

ŽIVČIĆ-BEĆİEVIĆ, I., SMOJVER-AŽIĆ, S. MARTINAC DORČIĆ, T.: GOD. 29 (2020), BR. 2, PERCEPTION OF..

Buhl, H. M., \& Lanz, M. (2007). Emerging adulthood in Europe common traits and variability across five European countries. Journal of Adolescent Research, 22(5), 439-443. https://doi.org/10.1177/074355840 7306345

Caliendo, M., \& Schmidl, R. (2016). Youth unemployment and active labor market policies in Europe. IZA Journal of Labor Policy, 5(1), 1-30. https://doi.org/10.1186/s40173-016-0057-x

Chickering, A. W., \& Reisser, L. (1993). Education and identity: The Jossey-Bass higher and adult education series. San Francisco: Jossey-Bass.

Choroszewicz, M., \& Wolff, P. (2010). 51 million young EU lived with their parent(s) in 2008. In Eurostat - Statistics in Focus 50/2010, European Commission.

Ciairano, S., Rabaglietti, E., Roggero, A., \& Callari, T. C. (2010). Life satisfaction, sense of coherence and job precariousness in Italian young adults. Journal of Adult Development, 17(3), 177-189. https://doi. org/10.1007/s10804-010-9099-2

Crocetti, E., Tagliabue, S., Sugimura, K., Nelson, L. J., Takahashi, A., Niwa, T., \& Jinno, M. (2015). Perceptions of emerging adulthood: A study with Italian and Japanese university students and young workers. Emerging Adulthood, 3(4), 229-243. https://doi.org/10.1177/216769681 5569848

Diener, E., Emmons, R. A., Larsen, R. J., \& Griffin, S. (1985). The satisfaction with life scale. Journal of Personality Assessment, 49(1), 71-75. https://doi.org/10.1207/s15327752jpa4901_13

Eurostat (2018a). Unemployment statistics. Available at http://ec.europa. eu/eurostat/statistics-explained/pdfscache/1163.pdf.

Eurostat (2018b). Being young in Europe today - family and society. Available at http://ec.europa.eu/eurostat/statistics-explained/index.php/Being_young_in_Europe_today_-family_and_society.

Galambos, N. L., Barker, E. T., \& Krahn, H. J. (2006). Depression, self-esteem, and anger in emerging adulthood: Seven-year trajectories. Developmental Psychology, 42(2), 350-365. https://doi.org/10.1037/0012-1649. 42.2.350

Howard, A. L., Galambos, N. L., \& Krahn, H. J. (2010). Paths to success in young adulthood from mental health and life transitions in emerging adulthood. International Journal of Behavioral Development, 34(6), 538-546. https://doi.org/10.1177/0165025410365803

Iacovou, M. (2002). Regional differences in the transition to adulthood. The Annals of the American Academy of Political and Social Science, 580(1), 40-69. https://doi.org/10.1177/0002716202580001003

Kenny, M. E., \& Sirin, S. R. (2006). Parental attachment, self-worth, and depressive symptoms among emerging adults. Journal of Counseling \& Development, 84(1), 61-71. https://doi.org/10.1002/j.1556-6678. 2006.tb00380.x

Kins, E., \& Beyers, W. (2010). Failure to launch, failure to achieve criteria for adulthood? Journal of Adolescent Research, 25(5), 743-777. https://doi. org/10.1177/0743558410371126

Kuwabara, S. A., Van Voorhees, B. W., Gollan, J. K., \& Alexander, G. C. 
DRUŠ. ISTRAŽ. ZAGREB GOD. 29 (2020), BR. 2, STR. 195-215

ŽIVČIĆ-BEĆIREVIĆ, I., SMOJVER-AŽIĆ, S., MARTINAC DORČIĆ, T.: PERCEPTION OF...
Disorder, development, and social context. General Hospital Psychiatry, 29(4), 317-324.

Lovibond, S. H., \& Lovibond, P. F. (1995). Manual for the Depression Anxiety Stress Scales (DASS). New South Wales: Psychology Foundation Monograph. https://doi.org/10.1037/t01004-000

Lowe, S. R., Dillon, C.O., Rhodes, J. E., \& Zwiebach, L. (2013). Defining adult experiences: Perspectives of a diverse sample of young adults. Journal of Adolescent Research, 28(1), 31-68. https://doi.org/10.1177/07 43558411435854

Macek, P., Bejček, J., \& Vaníčková, J. (2007). Contemporary Czech emerging adults: Generation growing up in the period of social changes. Journal of Adolescent Research, 22(5), 444-475. https://doi.org/ 10.1177/0743558407305417

Matković, T. (2008). Tko što radi? Dob i rod kao odrednice položaja na tržištu rada u Hrvatskoj [Who does what? Age and gender as determinants of the position on the labour market in Croatia]. Revija za socijalnu politiku, 15(3), 479-502. https://doi.org/10.3935/rsp.v15i3.802 McGee, R. E., \& Thompson, N. J. (2015). Unemployment and depression among emerging adults in 12 states, Behavioral Risk Factor Surveillance System, 2010. Preventing Chronic Disease, 12(3), Article 140451. https://doi.org/10.5888/pcd12.140451

Mortimer, J. T., Vuolo, M., Staff, J., Wakefield, S., \& Xie, W. (2008). Tracing the timing of "career" acquisition in a contemporary youth cohort. Work and Occupations, 35(1), 44-84. https://doi.org/10.1177/07 30888407309761

Nelson, L. J., \& Barry, C. M. (2005). Distinguishing features of emerging adulthood: The role of self-classification as an adult. Journal of Adolescent Research, 20(2), 242-262. https://doi.org/10.1177/074355840 4273074

Nelson, L. J., \& Luster, S. S. (2015). "Adulthood" by whose definition? The complexity of emerging adults' conceptions of adulthood. In J. J. Arnett (Ed.) The Oxford handbook of emerging adulthood (pp. 421-437). New York, NY: Oxford University Press. https://doi.org/10.1093/oxford$\mathrm{hb} / 9780199795574.013 .24$

Nelson, L. J., Willoughby, B. J., Rogers, A. A., \& Padilla-Walker, L. M. (2015). "What a view!" Associations between young people's views of the late teens and twenties and indices of adjustment and maladjustment. Journal of Adult Development, 22(3), 125-137. https://doi.org/ 10.1007/s10804-015-9206-5

Padilla-Walker, L. M., Nelson, L. J., \& Carroll, J. S. (2012). Affording emerging adulthood: Parental financial assistance of their college-aged children. Journal of Adult Development, 19(1), 50-58. https://doi.org/ 10.1007/s10804-011-9134-y

Paul, K. I., \& Moser, K. (2009). Unemployment impairs mental health: Meta-analyses. Journal of Vocational Behavior, 74(3), 264-282. https://doi.org/10.1016/j.jvb.2009.01.001

Piumatti, G., Giannotta, F., Roggero, A., \& Rabaglietti, E. (2013). Working status and perception of adulthood: A comparison between Italian and Dutch emerging adults. Psihološka obzorja/Horizons of Psychology, 22, 39-50. https://doi.org/10.20419/2013.22.374 
DRUŠ. ISTRAŽ. ZAGREB GOD. 29 (2020), BR. 2, STR. 195-215

ŽIVČIĆ-BEĆİEVIĆ, I., SMOJVER-AŽIĆ, S. MARTINAC DORČIĆ, T.: PERCEPTION OF...
Schulenberg, J. E., \& Schoon, I. (2012). The transition to adulthood across time and space: Overview of Special Section. Longitudinal and Life Course Studies, 3(2), 164-172. https://doi.org/10.14301/llcs.v3i2.194

Schulenberg, J. E., \& Zarrett, N. R. (2006). Mental health during emerging adulthood: Continuity and discontinuity in courses, causes, and functions. In J. J. Arnett \& J. L. Tanner (Eds.), Emerging adults in America: Coming of age in the 21st century (pp. 135-172). Washington DC: American Psychological Association. https://doi.org/10.1037/11381-006

Schwartz, S. J., Côté, J. E., \& Arnett, J. J. (2005). Identity and agency in emerging adulthood: Two developmental routes in the individualization process. Youth $\mathcal{E}$ Society, 37(2), 201-229. https://doi.org/ 10.1177/0044118X05275965

Seiffge-Krenke, I. (2013). "She's leaving home...": Antecedents, consequences, and cultural patterns in the leaving home process. Emerging Adulthood, 1(2), 114-124. https://doi.org/10.1177/2167696813479783

Seiffge-Krenke, I. (2016). Experiencing the transition to adulthood in Germany: Including emerging adults of the "forgotten half". In R. Žukauskiené (Ed.), Emerging adulthood in a European context (pp. 79-93). New York: Psychology Press.

Shanahan, M. J. (2000). Pathways to adulthood in changing societies: Variability and mechanisms in life course perspective. Annual Review of Sociology, 26(1), 667-692. https://doi.org/10.1146/annurev.soc.26.1.667 Sharon, T. (2016). Constructing adulthood. Markers of adulthood and well-being among emerging adults. Emerging Adulthood, 4(3), 161-167. https://doi.org/10.1177/2167696815579826

Sinclair, S. J., Siefert, C. J., Slavin-Mulford, J. M., Stein, M. B., Renna, M., \& Blais, M. A. (2012). Psychometric evaluation and normative data for the Depression, Anxiety, and Stress Scales-21 (DASS-21) in a nonclinical sample of U.S. Adults. Evaluation $\mathcal{E}$ the Health Professions, 35(3), 259-279. https://doi.org/10.1177/0163278711424282

Sirsch, U., Dreher, E., Mayr, E., \& Willinger, U. (2009). What does it take to be an adult in Austria? Views of adulthood in Austrian adolescents, emerging adults, and adults. Journal of Adolescent Research, 24(3), 275-292. https://doi.org/10.1177/0743558408331184

Spéder, Z., Murinkó, L., \& Settersten, R. A. (2014). Are conceptions of adulthood universal and unisex? Ages and social markers in 25 European countries. Social Forces, 92(3), 873-898. https://doi.org/10.1093/sf/sot100 Tagliabue, S., Lanz, M., \& Beyers, W. (2014). The transition to adulthood around the Mediterranean: Contributions of the special issue. Journal of Adolescence, 37(8), 1405-1408. https://doi.org/10.1016/j.adolescence.2014.09.001

Tanner, J. J. (2014). Mental health challenges of emerging adulthood. In J. J. Arnett (Ed.), Oxford handbook of emerging adulthood (pp. 499-520). New York: Oxford University Press.

Vleioras, G., \& Mantziou, A. (2018). Social role transitions and perceived adulthood status: Which ones matter for whom? Emerging Adulthood, 6(3), 200-205. https://doi.org/10.1177/2167696817722470

Zorotovich, J. R. (2014). Five dimensions of emerging adulthood: A comparison between students, nonstudents, and college graduates. (Unpublished $\mathrm{PhD}$ dissertation). University of Tennessee. 
DRUŠ, ISTRAŽ ZAGREB GOD. 29 (2020), BR. 2, STR. 195-215

ŽIVČIĆ-BEĆIREVIĆ, I., SMOJVER-AŽIĆ, S., MARTINAC DORCIC, T.: PERCEPTION OF...
Zupančič, M., Komidar, L., \& Levpušček, M. P. (2014). Individuation in Slovene emerging adults: Its associations with demographics, transitional markers, achieved criteria for adulthood, and life satisfaction. Journal of Adolescence, 37(8), 1421-1433. https://doi.org/10.1016/ j.adolescence.2014.03.014

Zupančič, M., Friedlmeier, W., Puklek Levpušček, M., Sirsch, U., Bruckner-Feld, J., \& Horvat, M. (2014). Perceptions of achieved criteria for adulthood among Austrian, Slovene, and US students. SAGE Open, 4(4), 1-12. https://doi.org/10.1177/2158244014556997

Žukauskiené, R. (2016). The experience of being an emerging adult in Europe. In R. Žukauskiené (Ed.), Emerging adulthood in a European context (pp. 3-16). New York: Psychology Press. https://doi.org/10.4324/ 9781315750620

\section{Percepciia odraslosti i psihološka prilagodba na nadolazeću odraslost}

\author{
Ivanka ŽIVČıĆ-BEĆIREVIĆ, Sanja SMOJVER-AŽıĆ, \\ Tamara MARTINAC DORCIĆ \\ Filozofski fakultet, Rijeka
}

Jedan od cilieva istraživanja bio je ispitati razlike u percepciij statusa odraslosti i ostvarenosti subjektivnih kriterija odraslosti s obzirom na spol i tranzicijska obiliežja (profesionalni status i život s roditeljima). Osim toga željelo se provjeriti doprinos tranzicijskih obiliežja, ostvarenih subjektivnih kriterija odraslosti i percipiranoga statusa odraslosti objašnjenju anksioznosti, depresivnosti i zadovoljstva životom. U istraživanju je sudjelovalo 572 studenata, zaposlenih i nezaposlenih mladih. Primijenjena je Skala depresije, anksioznosti i stresa (DASS), Skala zadovoljstva životom i Upitnik kriterija odraslosti. Rezultati su pokazali da zaposleni mladi odrasli percipiraju najviše postignutih kriterija odraslosti. Nakon kontrole tranzicijskih markera, manje dostignutih kriterija odraslosti predviđa više anksioznih i depresivnih simptoma. Mladi u razdoblju nadolazeće odraslosti, koji percipiraju više postignutih kriterija odraslosti i koji se osjećaju odraslima, jesu i zadovoljniji svojim životom. Nezaposleni mladi odrasli, osobito muškarci, imaju najveći rizik za razvoj poteškoća u psihološkoj prilagodbi, jer se više bore s punim ostvarivanjem uloge odraslog.

Ključne riječi: anksioznost, depresija, zadovoljstvo životom, nadolazeća odraslost, kriteriji odraslosti

\section{(c) (i) \$}

Međunarodna licenca / International License:

Imenovanje-Nekomercijalno / Attribution-NonCommercial 